\title{
Geochemical characteristics of whole rock and minerals from the Late Cretaceous granitic rocks of the Rokko Mountains
}

\author{
Toshio ARAI* \\ * Graduate School of Science and Technology, Kobe University, \\ Tsurukabuto 3-11, Nada-ku, Kobe, Hyogo 657-8501, Japan
}

\begin{abstract}
The Rokko Mountains consist primarily of late Cretaceous granitic rocks. These are recognized as Nunobiki Granodiorite, Yahatadani Granite, Dobashi Quartz Diorite, and Rokko Granite. Based on grain size and texture, the Nunobiki Granodiorite is subdivided into a porphyritic and equigranular facies, whereas the vertically zoned Rokko Granite pluton is differentiated into fine-grained, medium -to coarse-grained, and micrographic facies. The fine-grained facies occurs at high altitude, and the medium -to coarse-grained granite is found at an intermediate to low altitude within the Rokko Mountains. The micrographic facies intrudes both of these varieties. The granitic rocks were analyzed for trace and rare earth elements and mineral composition. The fine and micrographic facies of the Rokko Granite have higher $\mathrm{Rb}, \mathrm{Nb}$, and $\mathrm{Y}$, and lower $\mathrm{Sr}$ and $\mathrm{Zr}$ when compared with the medium -to coarse-grained facies equivalents and have strong negative Eu anomalies in chondrite normalized REE patterns. In the Rokko Granite the Rb content decreases with an increase in Sr. Whole-rock chemistry indicates that the Rokko granitic magma formed a zoned magma chamber due to plagioclase crystal fractionation. Results of the least-square mass balance calculation for the major elements are in good agreement with the analysis data for Eu. The Rokko granitic magma was rich in the volatile components, $\mathrm{SiO}_{2}$, and $\mathrm{K}_{2} \mathrm{O}$ at the top of the magma chamber, whereas the base was more intermediate in chemical composition. The fine-grained facies has a low An content, and biotite in the fine and micrographic facies is rich in $\mathrm{Fe}$ and poor in $\mathrm{Mg}$. These chemical characteristics indicate that two facies are formed from a more differentiated magma than the medium -to coarse-grained facies.
\end{abstract}

Keywords: Rokko Mountains, Vertically zoned pluton, Zoned magma chamber

\section{INTRODUCTION}

The geology and petrography of the Rokko Mountains have been described by several authors (Uechi, 1937; Kasama, 1968; Huzita and Kasama, 1982; Huzita and Kasama, 1983; Nakaie and Nakajima, 1989; Arai and Tainosho, 2004). Uechi (1937) described the geology of the Rokko Mountains. Kasama (1968) divided the granitic rocks into the Nunobiki Granodiorite, the Dobashi Quartz Diorite, and the Rokko Granite, and suggested that the Nunobiki Granodiorite belongs to the Ryoke granitic rocks assemblage, that Rokko Granite belongs to the Sanyo granitic rocks group, and that the Dobashi Quartz Diorite is a large xenolithic body in the Rokko Granite. Nakaie and Nakajima (1989) distinguished granite within the southeastern part of the Rokko Mountains as distinct

doi: 10.2465/jmps.041120

T. Arai, 991d809n@y01.kobe-u.ac.jp Corresponding author from the Nunobiki Granodiorite and named it the Yahatadani Granite. Arai and Tainosho (2004) subdivided the Rokko Granite into medium -to coarse-grained, finegrained, and micrographic facies; and the Nunobiki Granodiorite into porphyritic and equigranular facies.

The Rokko Granite is a vertically zoned pluton (Arai and Tainosho, 2004). The fine-grained facies occur at higher altitude, the medium-grained facies at middle part, and coarse-grained facies lie beneath, within the Rokko Mountains (Fig. 1). The upper Rokko Granite is rich in $\mathrm{SiO}_{2}$ and $\mathrm{K}_{2} \mathrm{O}$, whereas beneath this zone the body is rich in $\mathrm{TiO}_{2}, \mathrm{MgO}$, and $\mathrm{CaO}$.

Petrological studies have been carried out on the Rokko Mountains granites, but geochemical investigations have hitherto only been performed for major elements (Arai and Tainosho, 2004), not for trace elements and mineral composition. This paper presents an analysis of the whole-rock and mineral chemistry of the Nunobiki 

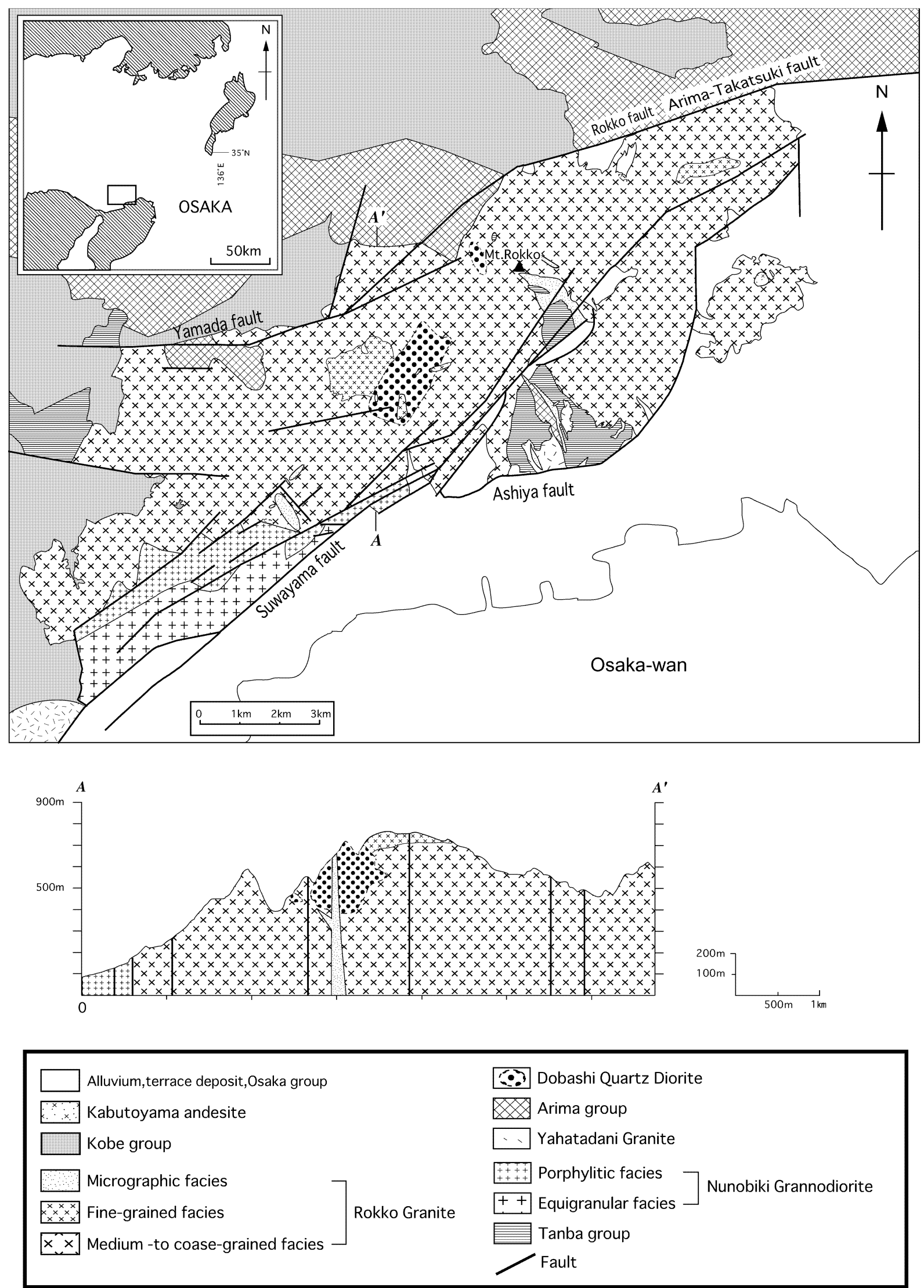

Figure 1. Geochemical map of the Rokko Mountains (modified after Arai and Tainosho, 2004). 
Table 1. Representative major and trace element composition of granitic rock

\begin{tabular}{|c|c|c|c|c|c|c|c|c|c|c|c|}
\hline \multirow[b]{4}{*}{ wt $\%$} & \multicolumn{6}{|c|}{ Rokko Granite } & \multicolumn{4}{|c|}{ Nunobiki Granodiorite } & \multirow{4}{*}{$\begin{array}{c}\text { Yahatadani Gr } \\
\\
030105 \\
-12\end{array}$} \\
\hline & \multicolumn{2}{|c|}{$\begin{array}{l}\text { Medium-to coarse } \\
\text {-grained }\end{array}$} & \multicolumn{2}{|c|}{ Fine-grained } & \multicolumn{2}{|c|}{ Micrographic } & \multicolumn{2}{|c|}{ Porphylitic } & \multicolumn{2}{|c|}{ Equigranular } & \\
\hline & 000416 & 000604 & 000709 & 000709 & 000604 & 000709 & 980905 & 981028 & 980605 & 991008 & \\
\hline & -4 & -3 & -3 & -8 & -4 & -7 & -5 & -2 & -2 & -1 & \\
\hline$\overline{\mathrm{SiO}_{2}}$ & 73.98 & 76.20 & 76.58 & 76.69 & 78.11 & 77.32 & 65.51 & 66.20 & 69.58 & 68.44 & 74.66 \\
\hline $\mathrm{TiO}_{2}$ & 0.15 & 0.09 & 0.05 & 0.05 & 0.05 & 0.07 & 0.54 & 0.51 & 0.47 & 0.50 & 0.16 \\
\hline $\mathrm{Al}_{2} \mathrm{O}_{3}$ & 13.79 & 12.28 & 12.69 & 12.35 & 12.60 & 12.52 & 15.63 & 15.77 & 14.64 & 14.49 & 13.08 \\
\hline Total- $\mathrm{Fe}_{2} \mathrm{O}_{3}$ & 2.56 & 1.76 & 1.21 & 1.43 & 1.36 & 1.03 & 5.49 & 5.03 & 4.72 & 4.53 & 2.72 \\
\hline $\mathrm{MnO}$ & 0.00 & 0.00 & 0.00 & 0.00 & 0.00 & 0.00 & 0.09 & 0.08 & 0.08 & - & 0.04 \\
\hline $\mathrm{MgO}$ & 0.30 & 0.12 & 0.11 & 0.08 & 0.07 & 0.06 & 2.15 & 1.92 & 1.52 & 1.58 & 0.23 \\
\hline $\mathrm{CaO}$ & 1.91 & 0.85 & 0.62 & 0.59 & 0.37 & 0.46 & 4.94 & 4.65 & 3.77 & 3.64 & 1.34 \\
\hline $\mathrm{Na}_{2} \mathrm{O}$ & 3.65 & 3.59 & 3.50 & 3.70 & 3.58 & 3.22 & 3.06 & 3.15 & 3.20 & 3.11 & 3.13 \\
\hline $\mathrm{K}_{2} \mathrm{O}$ & 3.39 & 4.10 & 4.56 & 4.39 & 4.56 & 4.67 & 2.23 & 2.37 & 2.77 & 2.95 & 4.13 \\
\hline $\mathrm{P}_{2} \mathrm{O}_{5}$ & 0.03 & 0.02 & 0.01 & 0.01 & 0.01 & 0.01 & 0.08 & 0.08 & 0.09 & 0.10 & 0.01 \\
\hline $\begin{array}{l}\text { Total } \\
\qquad \mathrm{ppm}\end{array}$ & 99.77 & 99.01 & 99.33 & 99.29 & 100.71 & 99.36 & 99.72 & 99.76 & 100.84 & 99.34 & 99.50 \\
\hline $\mathrm{Zn}$ & 40.0 & 35.8 & 28.0 & 21.2 & 28.6 & 19.1 & 63.8 & 56.6 & 47.9 & 58.9 & 42.2 \\
\hline $\mathrm{Ga}$ & 15.5 & 17.0 & 17.0 & 14.8 & 16.2 & 15.5 & 15.4 & 14.4 & 15.5 & 16.5 & 16.5 \\
\hline $\mathrm{Rb}$ & 92.9 & 131.7 & 139.6 & 160.2 & 206.1 & 161.9 & 74.8 & 76.5 & 76.7 & 95.7 & 166.9 \\
\hline $\mathrm{Sr}$ & 218.9 & 78.9 & 72.5 & 17.7 & 13.4 & 45.7 & 317.3 & 307.8 & 254.0 & 273.6 & 192.4 \\
\hline $\mathrm{Y}$ & 15.5 & 41.9 & 28.9 & 50.9 & 37.1 & 27.4 & 15.2 & 13.8 & 17.1 & 15.9 & 31.4 \\
\hline $\mathrm{Zr}$ & 129.6 & 104.2 & 119.7 & 131.5 & 109.8 & 111.4 & 129.7 & 115.3 & 115.3 & 140.6 & 140.0 \\
\hline $\mathrm{Ba}$ & 625.7 & 895.1 & 0.0 & 342.3 & 383.3 & 738.0 & 504.8 & 518.0 & 420.0 & 587.4 & 852.5 \\
\hline $\mathrm{Pb}$ & 18.7 & 19.1 & 27.5 & 28.9 & 29.0 & 19.8 & & 15.4 & 15.0 & 16.5 & 21.7 \\
\hline Th & 11.4 & 14.0 & 12.0 & 12.7 & 16.1 & 12.2 & & & 10.9 & 9.5 & 15.8 \\
\hline $\mathrm{Nb}$ & 6.1 & 11.3 & 7.3 & 12.0 & 15.1 & 11.4 & 5.6 & 4.7 & 6.3 & 5.6 & 7.5 \\
\hline $\mathrm{A} /(\mathrm{CNK})$ & 1.05 & 1.03 & 1.07 & 1.04 & 1.10 & 1.12 & 0.95 & 0.97 & 0.97 & 0.97 & 1.09 \\
\hline
\end{tabular}

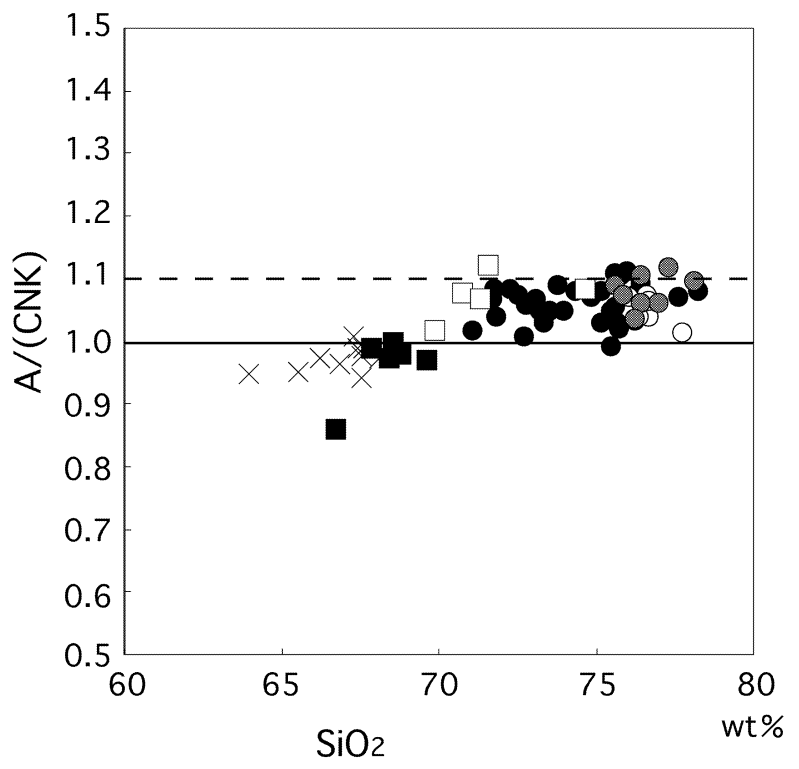

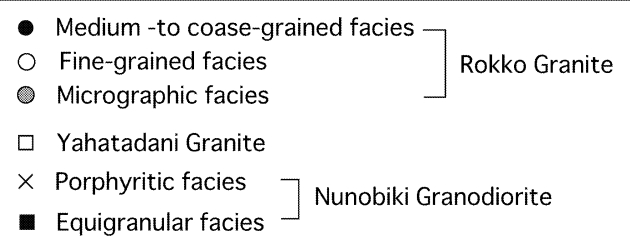

Figure 2. $\mathrm{SiO}_{2}-\mathrm{A} /(\mathrm{CNK})$ plots of the granitic rocks. Peraluminous and metaluminous fields are after Shand (1947).

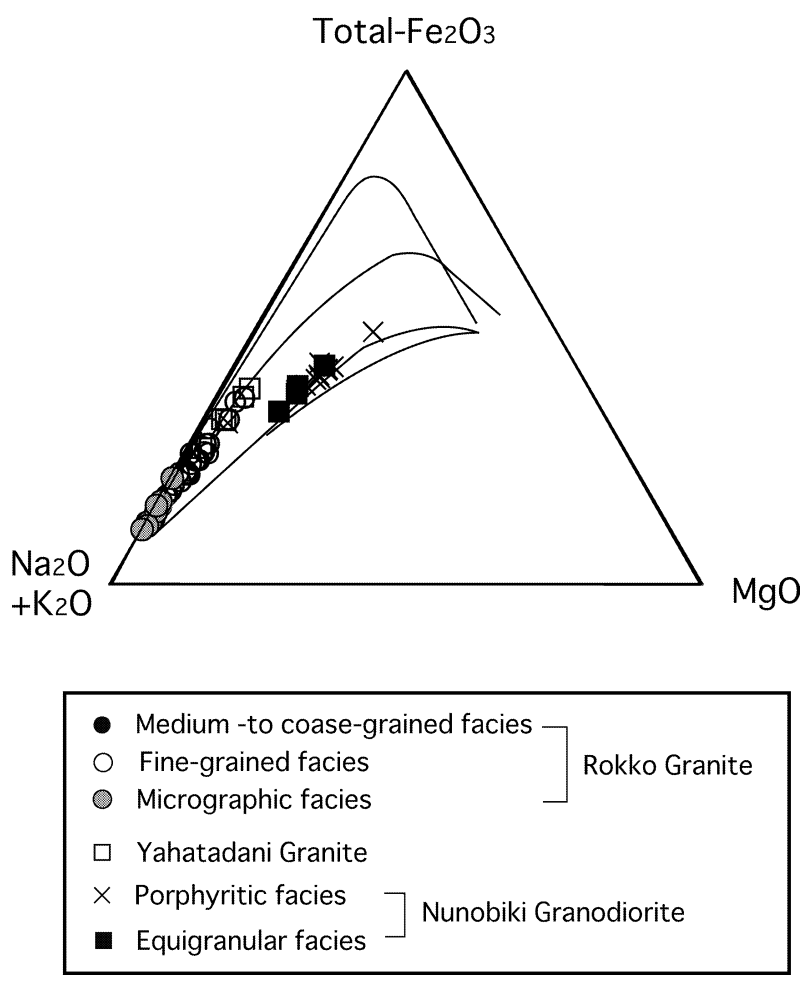

Figure 3. AFM diagram of the granitic rocks. The trends are after Miyashiro and Kushiro (1975). 

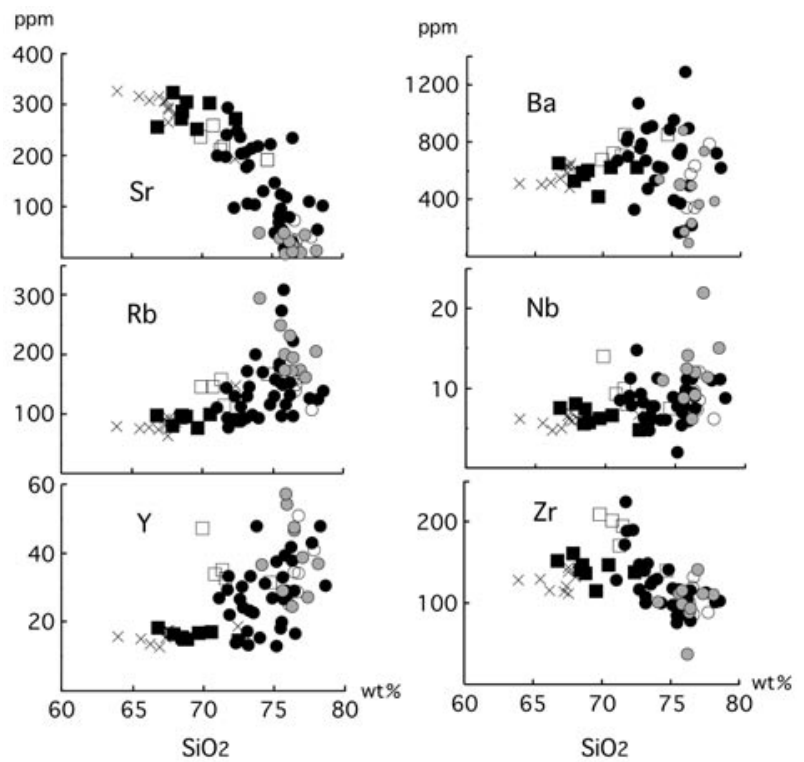

$\left.\begin{array}{l}\text { - } \text { Medium -to coase-grained facies } \\ 0 \text { Fine-grained facies } \\ 0 \text { Micrographic facies } \\ \square \text { Yahatadani Granite } \\ \times \text { Porphyritic facies } \\ \text { - Equigranular facies }\end{array}\right]$ Nunobiki Granodiorite

Figure 4. Harker diagram of $\mathrm{SiO}_{2}$ vs. trace elements for the granitic rocks.

Granodiorite, the Yahatadani Granite and the Rokko Granites, examines the geochemical variation and characteristics of these rocks, and discusses the mechanism of vertical zoning in the Rokko Granite.

\section{GEOLOGICAL SETTING}

The Rokko Mountains consist mainly of late Cretaceous granitic rocks (Fig. 1). The geology and petrography of this area have already been reported (Arai and Tainosho, 2004). The rocks are divided into the Nunobiki Granodiorite, the Yahatadani Granite, the Dobashi Quartz Diorite, and the Rokko Granite.

The Nunobiki Granodiorite belongs to the Younger Ryoke granitic rocks and occurs at the southern foot of the Rokko Mountains. It displays a weak gneissic fabric trending east- ${ }^{-}$west, dipping to the north. It contains numerous dark-colored, oval basic xenoliths, and is subdivided into porphyritic and equigranular facies. The porphyritic facies, which contains most of the xenoliths, occurs in the north, and the equigranular facies lie to the south. The boundary between the porphyritic and equigranular facies is gradational.

The Yahatadani Granite, which belongs to the Younger Ryoke granitic rocks, occurs as a small pluton in the southeastern Rokko Mountains and possesses a weak gneissic structure. Both the Yahatadani Granite and the Nunobiki Granodiorite have undergone weak Ryoke metamorphism and are therefore contemporaneous intrusive bodies.

Xenoliths predominating in the central partof the Rokko Granite are named the Dobashi Quartz Diorite (Kasama, 1968). Relatively larger angular-shaped xenolithic blocks up to $1 \mathrm{~m}$ in diameter are centrally concentrated and these grade into smaller oval-shaped inclusions towards the margin.

The Rokko Granite constitutes the major proportion of the Rokko Mountains. It belongs to the Sanyo belt of granite and is subdivided into medium -to coarsegrained, fine-grained, and micrographic facies based on grain size and texture. The medium -to coarse-grained $(>1.0 \mathrm{~mm})$ facies predominates. The fine-grained $(<1.0$ $\mathrm{mm}$ ) facies lies uppermost in the mountain topography, and the boundary between the medium -to coarse and fine-grained facies is gradational. The micrographic facies occurs as a dyke rock and intrudes both the other facies. The Rokko Granite intrudes the Nunobiki Granodiorite. At the contact the fine-grained facies of the Rokko Granite occurs.

$\mathrm{K}$-Ar geochronology of the Nunobiki Granodiorite reveals a $70.8 \pm 4.9 \mathrm{Ma}$ for hornblende (Matsuura et al., 1995). A K-Ar age for biotite from the Rokko Granite is $72 \mathrm{Ma}$ (Kawano and Ueda, 1966), and an Rb-Sr biotite whole-rock age is $71.2 \pm 1.5 \mathrm{Ma}$ (Terakado and Nohda, 1993).

The vertically zoned Rokko Granite pluton displays a finer grain size upwards (Fig. 1). In the medium -to coarse-grained facies, the coarse-grained facies with quartz grains larger than $1 \mathrm{~cm}$ in diameter occurs at altitudes of about $100 \mathrm{~m}$. With altitude, the quartz crystal diameter decreases (Arai and Tainosho, 2004).

\section{GENERAL PETROGRAPHY}

\section{Nunobiki Granodiorite}

This unit is a hornblende-biotite granodiorite. The porphyritic facies bears plagioclase phenocrysts and the rock includes many dark-colored basic oval xenoliths. It is composed mainly of plagioclase, alkali feldspar, quartz, biotite, and hornblende, with accessories such as zircon, allanite, apatite, titanite, and ilmenite. The equigranular facies carries euhedral hornblende but its primary constituent minerals are identical to those of the porphyritic facies. This rock contains some xenoliths. 

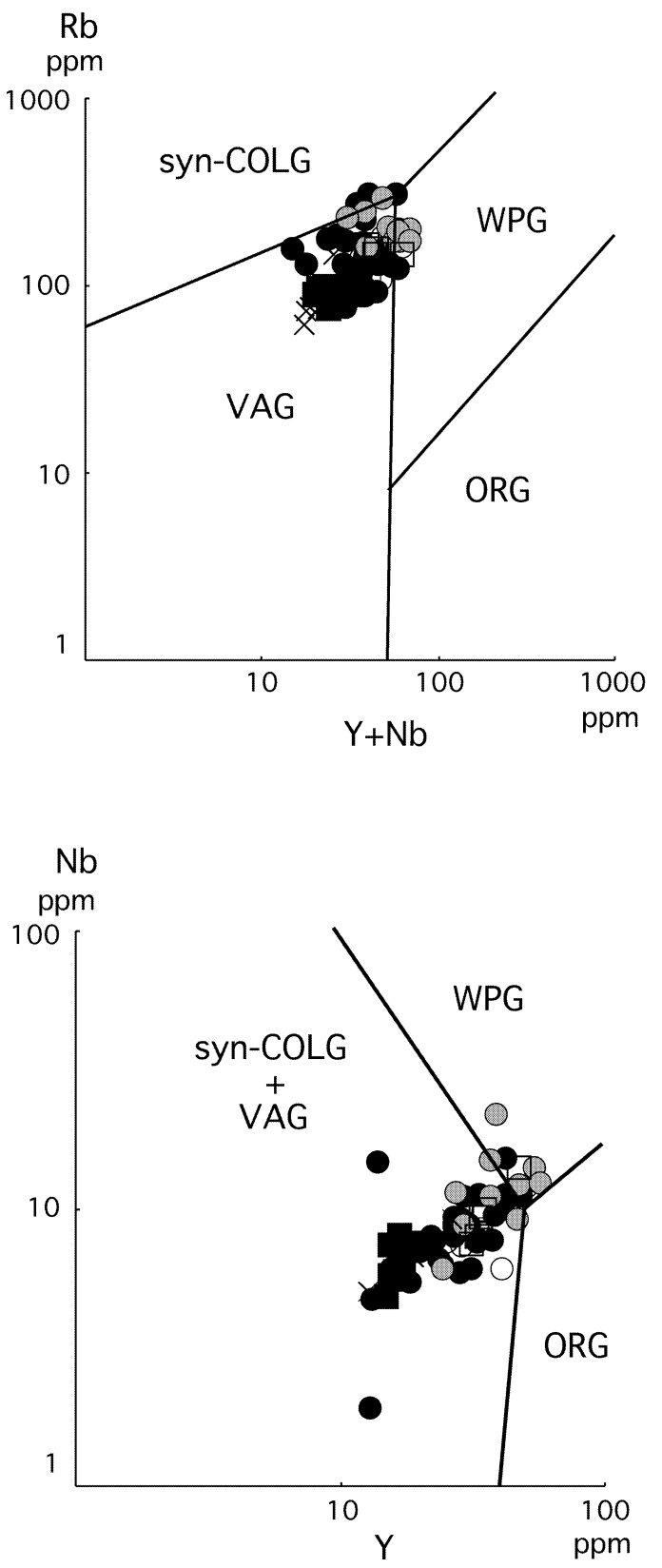

Figure 5. $\mathrm{Rb}$ vs. $(\mathrm{Y}+\mathrm{Nb})$ and $\mathrm{Nb}$ vs. $\mathrm{Y}$ discrimination diagrams (Pearce et al., 1984) for the granitic rocks.

\section{Yahatadani Granite}

An extremely heterogeneous hornblende-biotite body ranging from granite to quartz monzonite. It is composed mainly of quartz, alkali feldspar, plagioclase, biotite, and hornblende, accompanied by accessories such as allanite, apatite, titanite, zircon, and an opaque mineral.

\section{Rokko Granite}

A biotite granite which is subdivided into medium -to coarse-grained, fine-grained, and micrographic facies.

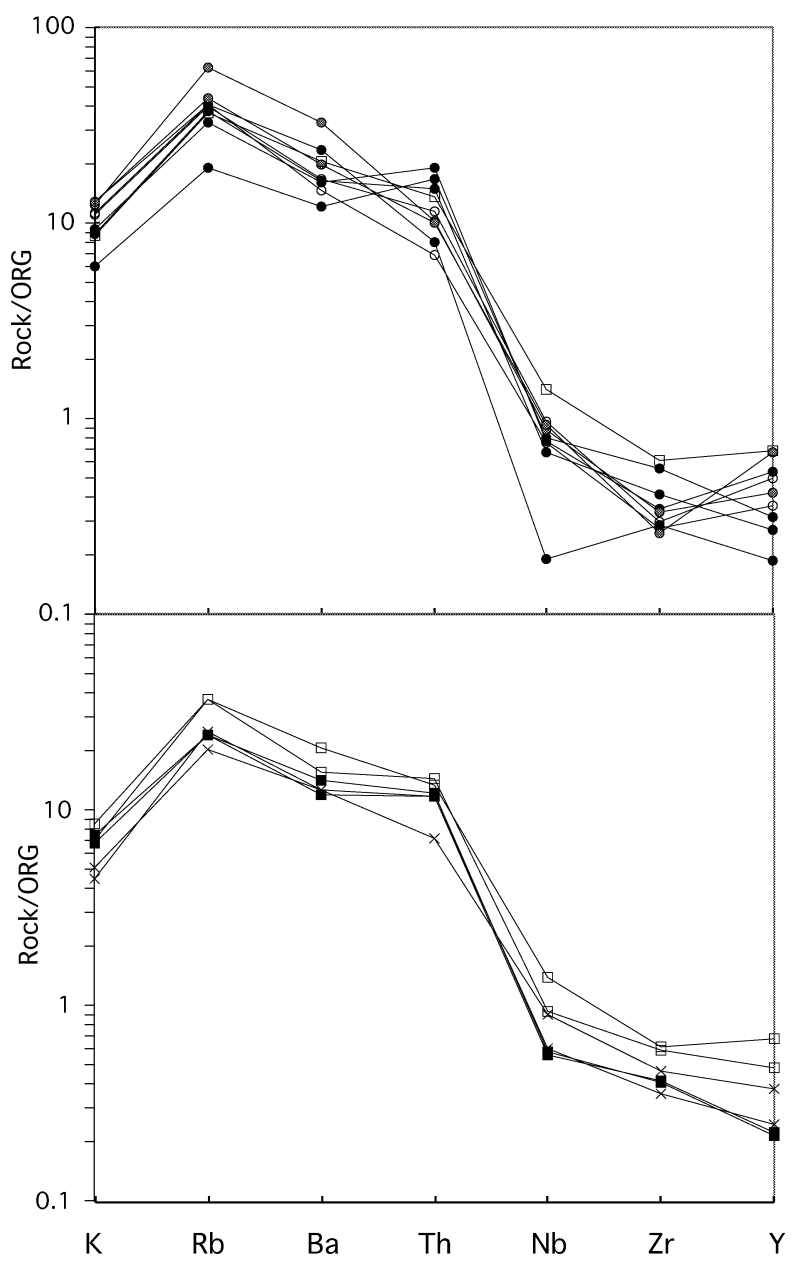

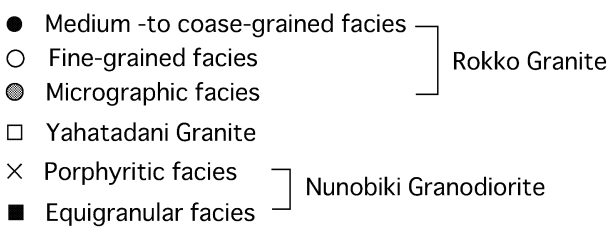

Figure 6. Ocean-ridge granite (ORG)-normalized (Pearce et al., 1984) geochemical patterns of granitic rocks.

The medium -to coarse-grained and fine-grained facies contain pink alkali feldspar. The micrographic facies and part of the fine-grained facies have miarolitic cavities. The primary constituent minerals of all three facies are alkali feldspar, plagioclase, quartz, and biotite, with accessories such as allanite, apatite, titanite, zircon, ilmenite, and rarely, magnetite. The medium -to coarse-grained facies has more amounts of mafic minerals than the other two rock facies (Arai and Tainosho, 2004). 
Table 2. Representative rare earth element composition of granitic rock

\begin{tabular}{|c|c|c|c|c|c|c|}
\hline \multirow[b]{2}{*}{ ppm } & \multicolumn{3}{|c|}{ Rokko Granite } & \multicolumn{2}{|c|}{ Nunobiki Granodiorite } & \multirow{2}{*}{$\begin{array}{c}\text { Yahatadani G } \\
020307-7 \\
\end{array}$} \\
\hline & $\begin{array}{c}\text { Coarse } \\
000604-8 \\
\end{array}$ & $\begin{array}{c}\text { Fine-grained } \\
000709-8 \\
\end{array}$ & $\begin{array}{c}\text { Micrographic } \\
000709-7 \\
\end{array}$ & $\begin{array}{c}\text { Equigranular } \\
980605-2 \\
\end{array}$ & $\begin{array}{c}\text { Porphylitic } \\
980905-5 \\
\end{array}$ & \\
\hline $\mathrm{La}$ & 30.59 & 29.51 & 10.89 & 24.57 & 24.46 & 27.77 \\
\hline $\mathrm{Ce}$ & 38.99 & 47.99 & 20.83 & 45.97 & 44.78 & 56.32 \\
\hline $\operatorname{Pr}$ & 6.01 & 7.53 & 2.46 & 4.47 & 4.31 & 6.07 \\
\hline $\mathrm{Nd}$ & 22.68 & 32.03 & 9.72 & 15.23 & 15.32 & 24.53 \\
\hline $\mathrm{Sm}$ & 3.87 & 7.68 & 2.40 & 2.88 & 2.81 & 4.96 \\
\hline $\mathrm{Eu}$ & 0.74 & 0.26 & 0.31 & 0.82 & 0.84 & 0.99 \\
\hline Gd & 3.62 & 7.36 & 2.88 & 2.43 & 2.46 & 4.55 \\
\hline $\mathrm{Tb}$ & 0.60 & 1.36 & 0.64 & 0.41 & 0.40 & 0.83 \\
\hline Dy & 3.51 & 8.05 & 4.33 & 2.47 & 2.41 & 4.79 \\
\hline Ho & 0.74 & 1.68 & 1.01 & 0.50 & 0.49 & 1.02 \\
\hline $\mathrm{Er}$ & 2.37 & 5.11 & 3.29 & 1.55 & 1.52 & 3.10 \\
\hline $\mathrm{Tm}$ & 0.37 & 0.77 & 0.53 & 0.24 & 0.23 & 0.47 \\
\hline $\mathrm{Yb}$ & 2.38 & 4.99 & 3.56 & 1.53 & 1.45 & 3.00 \\
\hline $\mathrm{Lu}$ & 0.37 & 0.75 & 0.55 & 0.23 & 0.22 & 0.42 \\
\hline
\end{tabular}

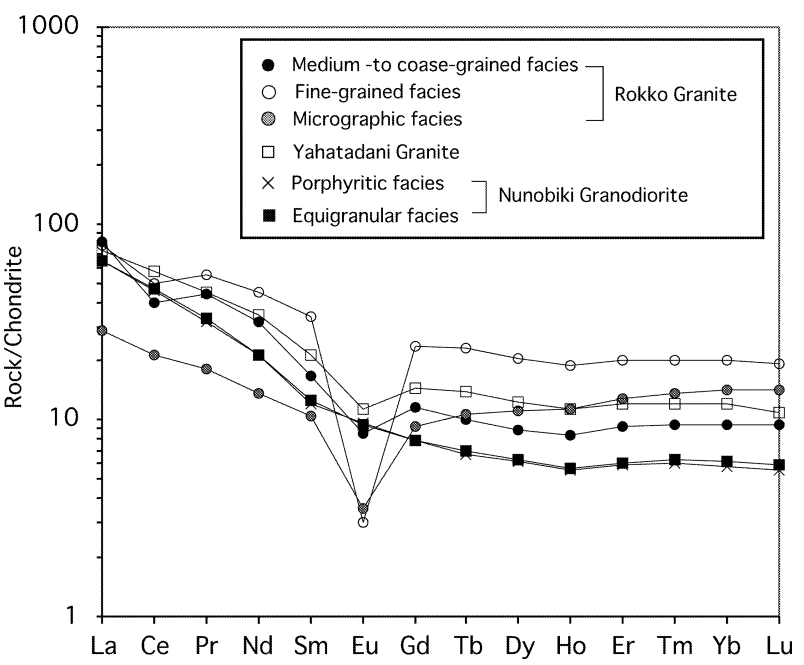

Figure 7. Chondrite-normalized REE patterns of the granitic rocks. Normalized values after Taylor and McLennan (1985).

\section{WHOLE-ROCK CHEMISTRY}

\section{Analytical methods}

Major and trace elements were analyzed by XRF (Rigaku $3270 \mathrm{E})$ at Kobe University following the analytical methods of Miyake et al. (1996), and Yamamoto and Morishita (1997). Rare earth elements were determined by ICP-MS at Actlabs. Ltd., Canada.

\section{Major elements}

Analyses for major elements within the granitic rocks of the Rokko Mountains have been reported (Arai and
Tainosho, 2004). Major elements for the typical rock types are listed in Table 1 . The $\mathrm{SiO}_{2}$ content of the porphyritic facies is $64-68 \mathrm{wt} \%$, and that of the equigranular facies is $66-71 \mathrm{wt} \% . \mathrm{SiO}_{2}$ in the Yahatadani Granite is 70-75 wt \%. The Rokko Granite has 71-78 wt $\% \mathrm{SiO}_{2}$ in the medium - to coarse-grained facies, $76-78 \mathrm{wt} \%$ in the fine-grained facies, and 74-78 wt $\%$ in the micrographic facies. The fine-grained and micrographic facies have higher $\mathrm{SiO}_{2}$ contents than the medium - to coarse-grained facies.

The Rokko Granite has high $\mathrm{K}_{2} \mathrm{O}$, but low $\mathrm{CaO}$, $\mathrm{MgO}$, $\mathrm{TiO}_{2}$, and $\mathrm{Fe}_{2} \mathrm{O}_{3}{ }^{*}$ (total iron as $\mathrm{Fe}_{2} \mathrm{O}_{3}$ ), whereas the Nunobiki Granodiorite has low $\mathrm{K}_{2} \mathrm{O}$ but high $\mathrm{CaO}, \mathrm{MgO}$, $\mathrm{TiO}_{2}$, and $\mathrm{Fe}_{2} \mathrm{O}_{3}{ }^{*}$ (Arai and Tainosho, 2004). The Rokko Granite thus has a chemical composition that is considerably different to that of the Nunobiki Granodiorite.

The Yahatadani Granite has a composition intermediate between the Rokko Granite and the Nunobiki Granodiorite. In the $\mathrm{SiO}_{2}-(\mathrm{A} / \mathrm{CNK})$ diagram (Fig. 2), the Nunobiki Granodiorite and the Dobashi Quartz Diorite have low A/CNK ratios (less than 1.0), the majorities of which plot in a metaluminous field. However, the Rokko Granite and the Yahatadani Granite plot in a peraluminous field because of high $\mathrm{SiO}_{2}$ content. The peraluminous and metaluminous fields used are those determined by Shand (1947). In the (AFM) diagram, the Rokko Granite and the Yahatadani Granite trend differently to the Nunobiki Granodiorite (Fig. 3). 


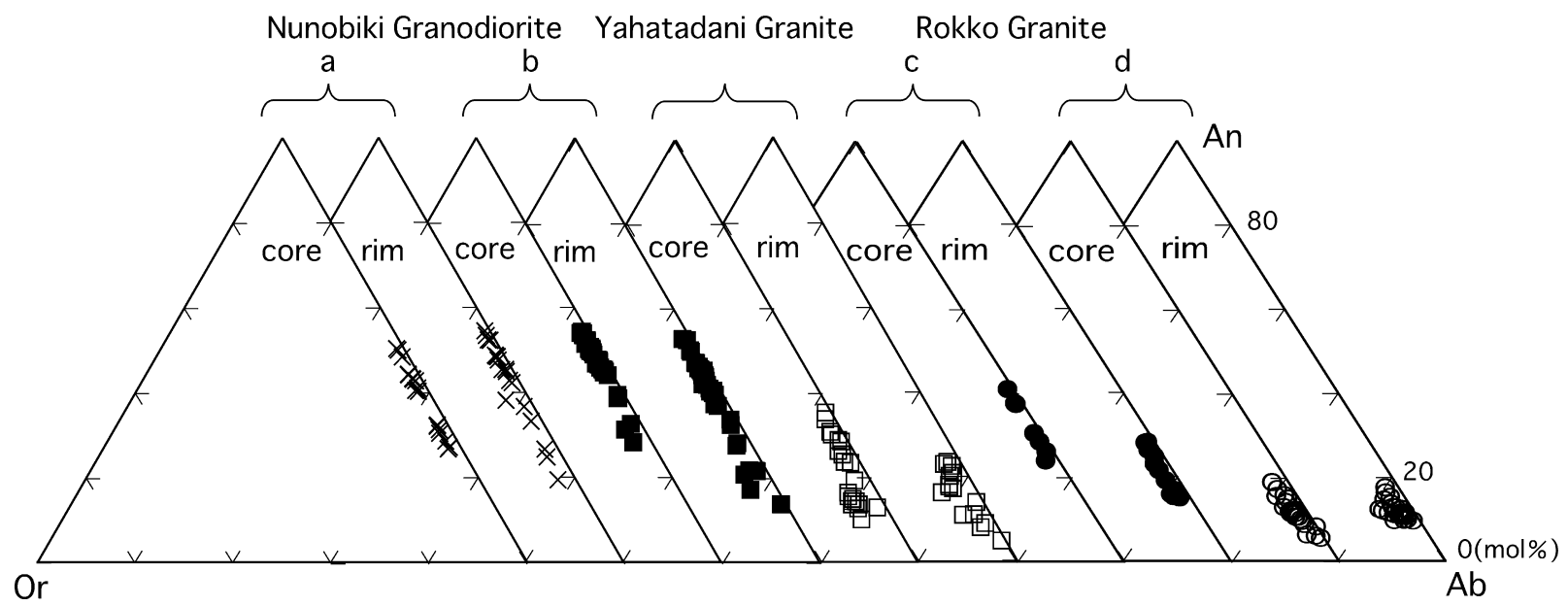

Figure 8. Or- $\mathrm{Ab}-\mathrm{An}$ plots of plagioclase in the granitic rock. Nunobiki Granodiorite and Rokko Granite are after Arai and Tainosho (2004). a: Porphyritic facies, b: Equigranular facies, c: Medium -to coarse-grained facies, d: Fine-grained facies.

Table 3. Representative chemical composition of plagioclase in granitic rock

\begin{tabular}{|c|c|c|c|c|c|c|c|c|c|c|}
\hline \multirow[b]{3}{*}{$w t \%$} & \multicolumn{4}{|c|}{ Rokko Granite } & \multicolumn{4}{|c|}{ Nunobii Granodiorite } & \multicolumn{2}{|c|}{ Yahatadani Granite } \\
\hline & \multicolumn{2}{|c|}{$\begin{array}{l}\text { Medium- to coarse } \\
\text {-grained }\end{array}$} & \multicolumn{2}{|c|}{ Fine-grained } & \multicolumn{2}{|c|}{ Porphylitic } & \multicolumn{2}{|c|}{ Equigranular } & \multirow[b]{2}{*}{ Core } & \multirow[b]{2}{*}{ Rim } \\
\hline & Core & Rim & Core & Rim & Core & Rim & Core & Rim & & \\
\hline$\overline{\mathrm{SiO}_{2}}$ & 60.65 & 63.23 & 66.73 & 66.73 & 58.04 & 57.02 & 56.70 & 58.63 & 59.94 & 64.58 \\
\hline $\mathrm{TiO}_{2}$ & 0.00 & 0.03 & 0.00 & 0.00 & 0.00 & 0.01 & 0.01 & 0.04 & 0.00 & 0.00 \\
\hline $\mathrm{Al}_{2} \mathrm{O}_{3}$ & 23.64 & 21.62 & 20.72 & 20.99 & 25.25 & 26.85 & 27.58 & 26.25 & 25.21 & 21.66 \\
\hline $\mathrm{FeO}$ & 0.19 & 0.13 & 0.07 & 0.03 & 0.23 & 0.18 & 0.17 & 0.19 & 7.09 & 3.47 \\
\hline $\mathrm{MnO}$ & 0.00 & 0.00 & 0.00 & 0.00 & 0.00 & 0.00 & 0.00 & 0.03 & 0.00 & 0.00 \\
\hline $\mathrm{MgO}$ & 0.00 & 0.00 & 0.01 & 0.02 & 0.01 & 0.00 & 0.01 & 0.03 & 0.01 & 0.02 \\
\hline $\mathrm{CaO}$ & 5.98 & 4.19 & 2.38 & 2.14 & 7.88 & 9.52 & 10.39 & 8.53 & 0.19 & 0.76 \\
\hline $\mathrm{Na}_{2} \mathrm{O}$ & 7.33 & 8.06 & 9.19 & 9.54 & 6.21 & 5.44 & 5.47 & 6.32 & 6.99 & 8.62 \\
\hline $\mathrm{K}_{2} \mathrm{O}$ & 0.21 & 0.40 & 0.39 & 0.47 & 0.34 & 0.24 & 0.31 & 0.34 & 0.14 & 0.11 \\
\hline $\mathrm{P}_{2} \mathrm{O}_{5}$ & 0.00 & 0.00 & 0.00 & 0.02 & 0.01 & 0.05 & 0.01 & 0.03 & 0.00 & 0.00 \\
\hline Total & 98.00 & 97.66 & 99.49 & 99.94 & 97.97 & 99.31 & 100.65 & 100.39 & 99.57 & 99.22 \\
\hline \multicolumn{11}{|c|}{ Cation $(\mathrm{O}=32)$} \\
\hline $\mathrm{Si}$ & 11.97 & 12.44 & 12.81 & 12.76 & 11.54 & 11.22 & 11.06 & 11.40 & 11.68 & 12.51 \\
\hline $\mathrm{Ti}$ & 0.00 & 0.00 & 0.00 & 0.00 & 0.00 & 0.00 & 0.00 & 0.01 & 0.00 & 0.00 \\
\hline $\mathrm{Al}$ & 5.50 & 5.02 & 4.69 & 4.73 & 5.92 & 6.23 & 6.34 & 6.02 & 5.79 & 4.95 \\
\hline $\mathrm{Fe}$ & 0.03 & 0.02 & 0.01 & 0.01 & 0.04 & 0.03 & 0.03 & 0.03 & 1.48 & 0.72 \\
\hline $\mathrm{Mn}$ & 0.00 & 0.00 & 0.00 & 0.00 & 0.00 & 0.00 & 0.00 & 0.01 & 0.00 & 0.00 \\
\hline $\mathrm{Mg}$ & 0.00 & 0.00 & 0.00 & 0.00 & 0.00 & 0.00 & 0.00 & 0.01 & 0.00 & 0.00 \\
\hline $\mathrm{Ca}$ & 1.26 & 0.88 & 0.49 & 0.44 & 1.68 & 2.01 & 2.17 & 1.78 & 0.05 & 0.19 \\
\hline $\mathrm{Na}$ & 2.81 & 3.08 & 3.42 & 3.54 & 2.39 & 2.07 & 2.07 & 2.38 & 2.64 & 3.24 \\
\hline K & 0.05 & 0.10 & 0.10 & 0.11 & 0.09 & 0.06 & 0.08 & 0.08 & 0.02 & 0.02 \\
\hline $\mathrm{P}$ & 0.00 & 0.00 & 0.00 & 0.00 & 0.00 & 0.01 & 0.00 & 0.00 & 0.00 & 0.00 \\
\hline Total & 21.62 & 21.54 & 21.52 & 21.59 & 21.66 & 21.63 & 21.75 & 21.72 & 21.66 & 21.63 \\
\hline $\mathrm{An}(\mathrm{mol})$ & 30.67 & 21.78 & 12.21 & 10.70 & 40.38 & 48.44 & 50.28 & 41.87 & 35.50 & 17.36 \\
\hline
\end{tabular}

\section{Trace elements}

Representative trace analyses are listed in Table 1. Comparing the Rokko Granite with the Nunobiki Granodiorite, the Rokko Granite has greater amounts of Rb, Y, Ba, and $\mathrm{Nb}$, and lower $\mathrm{Sr}$ and $\mathrm{Zr}$. The fine-grained and micrographic facies of the Rokko Granite have higher $\mathrm{Rb}, \mathrm{Nb}$, and $\mathrm{Y}$, and lower $\mathrm{Sr}$ and $\mathrm{Zr}$ (Fig. 4). On the other hand, the Nunobiki Granodiorite in both the porphyritic and equigranular facies has high $\mathrm{Sr}$ and low $\mathrm{Rb}, \mathrm{Y}, \mathrm{Ba}$, and $\mathrm{Nb}$ (Fig. 4). These units are considerably different to each other.

The Yahatadani Granite has high $\mathrm{Sr}, \mathrm{Zr}$, and $\mathrm{Y}$, and low $\mathrm{Rb}$ and $\mathrm{Nb}$ compared with the Nunobiki Granodiorite (Fig. 4). In the discrimination diagrams in terms of tectonic setting of granites after Peace et al. (1984), all the 
Table 4. Representative chemical composition of biotite in granitic rock

\begin{tabular}{|c|c|c|c|c|c|c|}
\hline \multirow[b]{2}{*}{$\mathrm{wt}(\%)$} & \multicolumn{3}{|c|}{ Rokko Granite } & \multicolumn{2}{|c|}{ Nunobiki Granodiorite } & \multirow[t]{2}{*}{ Yahatadani Gr } \\
\hline & Medium & Fine-grained & Micrographic & Porphylitic & Equigranular & \\
\hline $\mathrm{SiO}_{2}$ & 35.28 & 35.41 & 35.41 & 36.86 & 36.24 & 34.69 \\
\hline $\mathrm{TiO}_{2}$ & 3.13 & 2.32 & 2.40 & 3.79 & 3.72 & 3.93 \\
\hline $\mathrm{Al}_{2} \mathrm{O}_{3}$ & 13.60 & 14.14 & 15.62 & 13.93 & 14.01 & 13.96 \\
\hline $\mathrm{FeO}$ & 28.01 & 31.52 & 30.94 & 22.38 & 23.82 & 30.32 \\
\hline $\mathrm{MnO}$ & 0.77 & 0.91 & 0.48 & 0.24 & 0.26 & 0.86 \\
\hline $\mathrm{MgO}$ & 4.28 & 2.12 & 1.54 & 9.74 & 9.18 & 5.17 \\
\hline $\mathrm{CaO}$ & 0.12 & 0.06 & 0.00 & 0.01 & 0.06 & 0.19 \\
\hline $\mathrm{Na}_{2} \mathrm{O}$ & 0.05 & 0.12 & 0.06 & 0.11 & 0.13 & 0.10 \\
\hline $\mathrm{K}_{2} \mathrm{O}$ & 8.89 & 8.60 & 9.21 & 9.74 & 9.28 & 8.07 \\
\hline Total & 94.13 & 95.20 & 95.66 & 96.80 & 96.70 & 97.29 \\
\hline \multicolumn{7}{|c|}{ Cations $(\mathrm{O}=22)$} \\
\hline $\mathrm{Si}$ & 5.72 & 5.76 & 5.70 & 5.64 & 5.58 & 5.48 \\
\hline $\mathrm{Ti}$ & 0.38 & 0.28 & 0.29 & 0.44 & 0.43 & 0.47 \\
\hline $\mathrm{Al}$ & 2.60 & 2.71 & 2.96 & 2.51 & 2.54 & 2.60 \\
\hline $\mathrm{Fe}$ & 3.80 & 4.29 & 4.16 & 2.86 & 3.07 & 4.01 \\
\hline $\mathrm{Mn}$ & 0.11 & 0.13 & 0.07 & 0.03 & 0.03 & 0.12 \\
\hline $\mathrm{Mg}$ & 1.03 & 0.51 & 0.37 & 2.22 & 2.11 & 1.22 \\
\hline $\mathrm{Ca}$ & 0.02 & 0.01 & 0.00 & 0.00 & 0.01 & 0.03 \\
\hline $\mathrm{Na}$ & 0.02 & 0.04 & 0.02 & 0.03 & 0.04 & 0.03 \\
\hline $\mathrm{K}$ & 1.84 & 1.78 & 1.89 & 1.90 & 1.82 & 1.63 \\
\hline Total & 15.52 & 15.51 & 15.46 & 15.63 & 15.63 & 15.59 \\
\hline Mg value & 0.21 & 0.10 & 0.08 & 0.43 & 0.40 & 0.23 \\
\hline
\end{tabular}

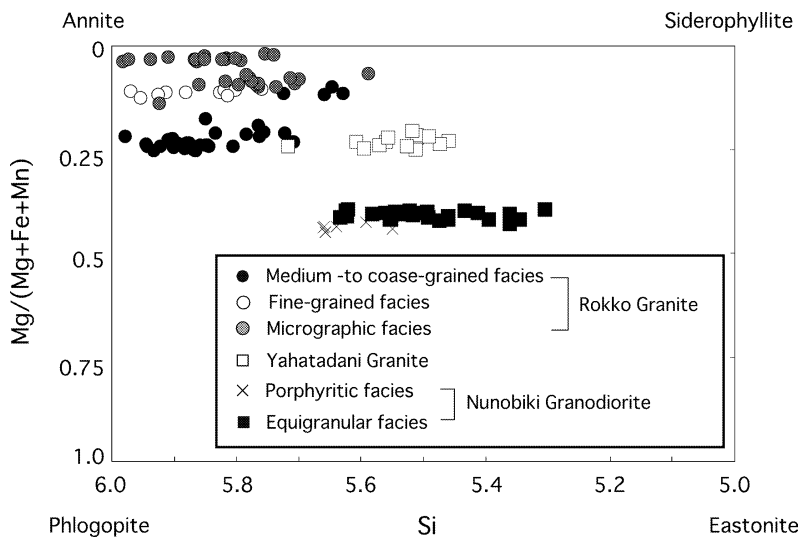

Figure 9. $\mathrm{Si}$ vs. $\mathrm{Mg} /(\mathrm{Mg}+\mathrm{Fe}+\mathrm{Mn})$ plots of biotite from granitic rock.

granitic rocks from the Rokko Mountains occur exclusively in the volcanic arc granite (VAG) field (Fig. 5). Spider diagrams normalized to ocean-ridge granite show that all the granitic rocks considered are enriched in the large ion lithophile (LIL) elements $\mathrm{K}, \mathrm{Rb}, \mathrm{Ba}$, and Th, and are depleted in the high field strength (HFS) elements $\mathrm{Nb}$, $\mathrm{Zr}$, and Y (Fig. 6).

\section{Rare earth elements}

The representative rare earth element analyses of granitic rocks are given in Table 2. Rare earth element totals of Rokko Mountains granites range from $63.4 \mathrm{ppm}$ to 155.1 ppm in the Rokko Granite; 138.8 ppm in the Yahatadani Granite; and 101.7 ppm to $103.3 \mathrm{ppm}$ in the Nunobiki Granodiorite.

The fine-grained facies of the Rokko Granite has a pronounced REE content, whereas the micrographic facies is REE depleted. The porphyritic and equigranular facies of the Nunobiki Granodiorite have identical REE.

Chondrite-normalized REE patterns are shown in Figure 7. These are somewhat sloped for ligth REE; however, they are comparatively flat for heavy REE.

The Rokko and Yahatadani Granites have clearly negative $\mathrm{Eu}$ anomalies, especially notable in the finegrained and micrographic facies of the Rokko Granite. However, the Nunobiki Granodiorite has no Eu anomaly and has low heavy REE when compared with the Rokko Granite, which signifies their difference. 
Table 5. Representative chemical composition of hornblende in Nunobiki Granodiorite

\begin{tabular}{|c|c|c|}
\hline \multirow[b]{2}{*}{$\operatorname{wt}(\%)$} & \multicolumn{2}{|c|}{ Nunobiki Granodiorite } \\
\hline & Porphylitic & Equigranular \\
\hline $\mathrm{SiO}_{2}$ & 52.03 & 50.47 \\
\hline $\mathrm{TiO}_{2}$ & 0.41 & 0.32 \\
\hline $\mathrm{Al}_{2} \mathrm{O}_{3}$ & 3.41 & 4.53 \\
\hline $\mathrm{FeO}^{*}$ & 17.33 & 18.42 \\
\hline $\mathrm{MnO}$ & 0.62 & 0.56 \\
\hline $\mathrm{MgO}$ & 12.90 & 12.19 \\
\hline $\mathrm{CaO}$ & 10.58 & 10.98 \\
\hline $\mathrm{Na}_{2} \mathrm{O}$ & 0.56 & 0.87 \\
\hline $\mathrm{K}_{2} \mathrm{O}$ & 0.26 & 0.36 \\
\hline Total & 98.10 & 98.70 \\
\hline \multicolumn{3}{|c|}{ Cations $(\mathrm{O}=23)$} \\
\hline $\mathrm{Si}$ & 7.62 & 7.43 \\
\hline $\mathrm{Ti}$ & 0.05 & 0.04 \\
\hline $\mathrm{Al}$ & 0.59 & 0.78 \\
\hline $\mathrm{Fe}$ & 2.12 & 2.27 \\
\hline $\mathrm{Mn}$ & 0.11 & 0.10 \\
\hline $\mathrm{Mg}$ & 2.82 & 2.67 \\
\hline $\mathrm{Ca}$ & 1.66 & 1.73 \\
\hline $\mathrm{Na}$ & 0.16 & 0.25 \\
\hline $\mathrm{K}$ & 0.05 & 0.07 \\
\hline Total & 15.18 & 15.34 \\
\hline Mg value & 0.56 & 0.53 \\
\hline
\end{tabular}

* Total iron as FeO.

Table 6. Mineral compositions used for the fractional crystallization modeling

\begin{tabular}{lcccc}
\hline & \multicolumn{2}{c}{ Plagioclase } & & Biotite \\
\cline { 2 - 3 } \cline { 5 - 5 } & $\mathrm{An} 38$ & $\mathrm{An} 16$ & & \\
$\mathrm{SiO}_{2}$ & 59.4 & 64.41 & & 35.67 \\
$\mathrm{TiO}_{2}$ & 0 & 0.04 & & 2.91 \\
$\mathrm{Al}_{2} \mathrm{O}_{3}$ & 25.01 & 21.61 & & 14.12 \\
$\mathrm{FeO}$ & 0.15 & 0.09 & & 27.23 \\
$\mathrm{MnO}$ & 0 & 0.02 & & 0.68 \\
$\mathrm{MgO}$ & 0 & 0.01 & & 4.23 \\
$\mathrm{CaO}$ & 7.27 & 3.05 & & 0.1 \\
$\mathrm{Na}$ & 6.47 & 8.87 & & 0.03 \\
$\mathrm{~K}_{2} \mathrm{O}$ & 0.21 & 0.45 & & 8.1 \\
$\mathrm{Total}$ & 98.51 & 98.55 & \\
\cline { 5 - 6 } & & & & 93.07 \\
\hline
\end{tabular}

\section{MINERAL CHEMISTRY}

\section{Analytical methods}

The mineral chemical analyses were undertaken using a JEOL-8900M electron probe microanalyzer at the Venture Business Laboratory of Kobe University. Element

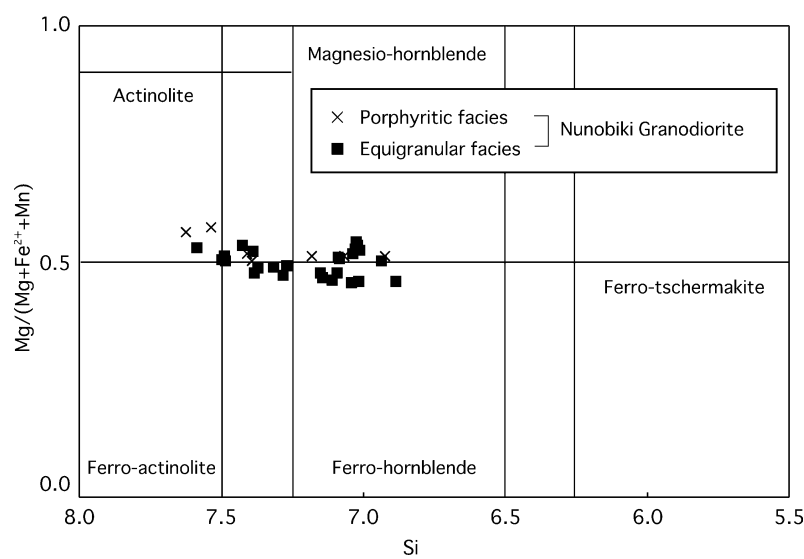

Figure 10. Plots of hornblende in the Nunobiki Granodiorite onto the classification diagram of calcic amphibole (Leake, 1978).
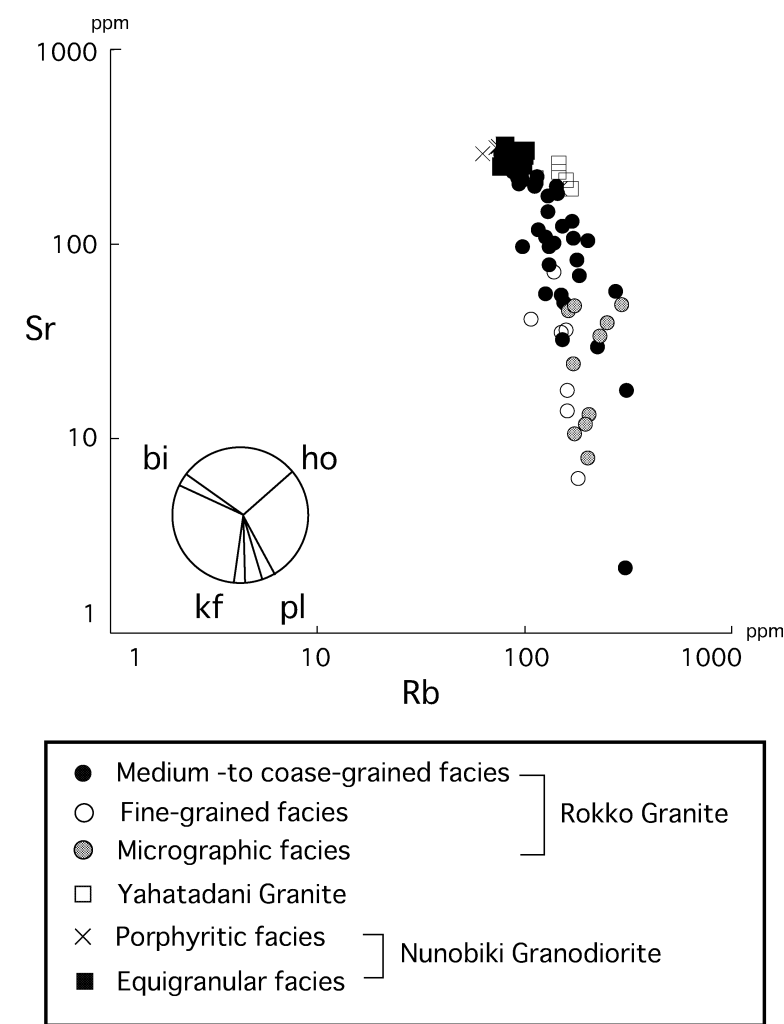

Figure 11. Sr vs. Rb plots for the granitic rock. Vectors of fractional crystallization are after Murata and Yoshida (1985).

determination was carried out using a beam size of $3 \mu \mathrm{m}$, an accelerating potential of $15 \mathrm{kV}$ with a probe current of $12 \mathrm{nA}$, and a count time of $20 \mathrm{~s}$ for each element analyzed. Matrix effects during analytical procedures were corrected using the ZAF software provided by JEOL.

\section{Plagioclase}

Plagioclase compositions for the Nunobiki Granodiorite and the Rokko Granite have been previously reported 
Table 7. Trace element partition coefficients between mineral and liquid used for fractional crystallization

\begin{tabular}{lcc}
\hline & Plgioclase & Biotite \\
$\mathrm{La}$ & 0.38 & 5.713 \\
$\mathrm{Ce}$ & 0.267 & 4.357 \\
$\mathrm{Nd}$ & 0.203 & 2.56 \\
$\mathrm{Sm}$ & 0.165 & 2.117 \\
$\mathrm{Eu}$ & 5.417 & 2.02 \\
$\mathrm{Dy}$ & 0.112 & 1.72 \\
$\mathrm{Yb}$ & 0.09 & 1.473 \\
$\mathrm{Lu}$ & 0.092 & 1.617 \\
\hline
\end{tabular}

After Nash and Crecraft (1985).

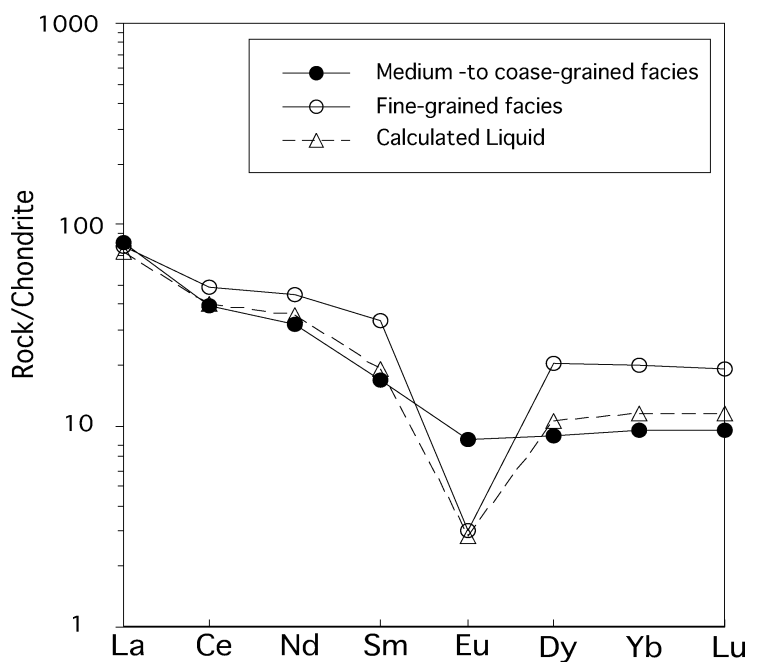

Figure 12. Chondrite-normalized REE pattern of liquid calculated in the Rayleigh fractionation modeling of parental magma (medium -to coarse-grained facies). The fine-grained facies is comparable to the calculated liquid composition for Eu.

(Arai and Tainosho, 2004). The plagioclase from the Rokko Mountains shows a chemical zonation (Arai and Tainosho, 2004). Core plagioclase composition in the Nunobiki Granodiorite ranges from An30 to An60 (Fig. 8). The rim ranges from An20 to An60.

Core composition of the medium to coarse-grained facies in Rokko Granite ranges from An25 to An45 (Fig. 8), whereas the rim ranges from An15 to An30. In contrast, the core of the fine-grained facies ranges from An5 to An20, and the rim also ranges from An5 to An20. The core plagioclase of the Yahatadani Granite varies from An10 to An40 (Fig. 8). The rim varies from An5 to An25.

Representative chemical analyses and the number of atoms derived for plagioclase from the granitic rocks in the Rokko Mountains are given in Table 3. The calculations were based upon 32 oxygen atoms per formula unit.
Table 8. Results of the fractional crystallization modeling

\begin{tabular}{lc}
\hline $\begin{array}{l}\text { Parental liquid } \\
\text { Daughter liquid }\end{array}$ & $\begin{array}{c}\text { Medium-to coase } \\
\text { Fine-grained facies }\end{array}$ \\
\hline $\begin{array}{l}\text { Model composition (wt.\%) } \\
\text { Plagioclase }\end{array}$ & 20.6 \\
Biotite & 4.85 \\
Liquid & 74.5 \\
& \\
RSS* & 0.59 \\
& \\
Calculated REE (ppm) & \\
La & 27.8 \\
Ce & 39.0 \\
Nd & 25.3 \\
Sm & 4.45 \\
Eu & 0.25 \\
Dy & 4.17 \\
Yb & 2.88 \\
Lu & 0.44 \\
\hline
\end{tabular}

\section{Biotite}

Representative chemical analyses of biotite in all the granitic rocks are given in Table 4. The number of atoms was calculated on the basis of 22 oxygens per formula unit. The $\mathrm{Mg}$ values $[\mathrm{Mg} /(\mathrm{Mg}+\mathrm{Fe}+\mathrm{Mn})]$ are shown in Figure 9. Biotites of the Rokko Granite are divided into two groups: biotites from the fine-grained and micrographic facies have a low $\mathrm{Mg}$ value (0.10) and are rich in annite content when compared with those from the medium -to coarse-grained facies.

The $\mathrm{Mg}$ values of the biotite in the Rokko Granite decrease with augmented whole-rock $\mathrm{SiO}_{2}$. On the other hand, the biotite of the Nunobiki Granodiorite is poor in $\mathrm{Si}$ content and has a greater $\mathrm{Mg}$ value (0.43). The biotites from both porphyritic and equigranular facies of the Nunobiki Granodiorite have the same Mg value. Biotite in the Yahatadani Granite has a similar Si content to that of the Nunobiki Granodiorite, but the $\mathrm{Mg}$ value of the biotite in the Yahatadani Granite is low (0.23) when compared with that of the Nunobiki Granodiorite.

\section{Hornblende}

Representative chemical analyses of hornblende are given in Table 5. The calculation was done on the basis of 23 oxygen atoms per formula unit, assuming all iron to be in the form of $\mathrm{FeO}$ because the opaque mineral of the Nunobiki Granodiorite is all ilmenite. The $\mathrm{Mg}$ value of the hornblende in the Nunobiki Granodiorite ranges from 
0.46 to 0.57 . Hornblende plots in an area near the boundary between actinolite, magnesio-, and ferro-hornblende (Fig. 10).

\section{DISCUSSION}

All the granitic rocks from the Rokko Mountains lie in the VAG field of the tectonic discrimination diagram (Fig. 5). The spider diagrams normalized to ocean-ridge granite show that all the granitic rocks in the Rokko Mountains are enriched in LIL elements and are depleted in HFS elements (Fig. 6). These results indicate that the rocks belong to the VAG group.

The Rokko Granite is rich in $\mathrm{A} /(\mathrm{CNK})$ with a ratio of approximately 1.1 (Fig. 2), and is also rich in $\mathrm{Ba}, \mathrm{Rb}, \mathrm{Y}$, and $\mathrm{Nb}$. The fine-grained and micrographic facies have high $\mathrm{Rb}, \mathrm{Nb}, \mathrm{Y}$, and $\mathrm{SiO}_{2}$, and low $\mathrm{Sr}$ and $\mathrm{Zr}$ when compared with the medium -to coarse-grained facies (Fig. 4).

The fine-grained and micrographic facies have strong negative $\mathrm{Eu}$ anomalies in chondrite-normalized REE patterns (Fig. 7). This can be explained by the crystal fractionation of plagioclase, where it can be observed that $\mathrm{Rb}$ decreases with an increase in $\mathrm{Sr}$ (Fig. 11). Through separation of plagioclase from the magma there was a depletion of $\mathrm{Sr}$, and relative enrichment in $\mathrm{Rb}$, revealing fractional crystallization of plagioclase in the Rokko Granite.

The crystal fractionation model was applied to these granites by employing the least-squares mass balance calculation for major elements. The most $\mathrm{SiO}_{2}$-depleted sample (the coarse-grained facies 000604-8, Table 2) was chosen as a starting composition. Mineral compositions used for the modeling are listed in Table 6. The highest An and lowest An content of plagioclases from the medium -to coarse-grained facies of the Rokko Granite were selected, and REE abundance in the fractionated melt was calculated using the Rayleigh fractional model. The liquid-crystal partition coefficients used for the modeling are listed in Table 7. Partition coefficients are those determined by Nash and Crecraft (1985). The GENMIX program (Le Maitre, 1981) was used for the calculation.

The fine-grained Rokko Granite can be derived by removing $21 \%$ of plagioclase and $5 \%$ of biotite from the medium -to coarse-grained facies (Table 8). The calculated compositions are in good agreement with the analytical data for Eu (Fig. 12). This mass balance calculation holds good since (RSS)(residual sum of squares) is less than 1.0 (Table 8). Compared with the biotite of the medium -to coarse-grained Rokko Granite, that of the fine-grained and micrographic facies is rich in $\mathrm{Fe}$ and poor in Mg (Fig. 9). These characteristics of mineral chemistry indicate that the two facies were formed from a more fractionated magma when compared with the medium -to coarse-grained facies, showing that the Rokko Granite was characterized by a crystal fractionation of plagioclase and biotite.

The Rokko Granite is a vertically zoned pluton (Arai and Tainosho, 2004) whose formation may be explained in the following manner.

The Rokko granitic magma had a vertical chemical zonation owing to the crystal fractionation of plagioclase and biotite. The top of the magma chamber achieved a higher felsic chemical component when compared with the base. The magma was rich in $\mathrm{SiO}_{2}, \mathrm{~K}_{2} \mathrm{O}$, and volatile components at the top of the chamber. When this magma intruded into a near-surface area, the pressure of the magma chamber abruptly decreased and the solidus temperature of the magma shifted to a high temperature field because of the rapid exit of volatile components. Arai and Tainosho (2004) recorded that the fine-grained facies has miarolitic cavities and local micrographic texture. These indicate that the Rokko granitic magma formed as a shallow intrusion.

The uppermost part of the intrusion cooled and solidified rapidly whereas the base experienced a relatively slower loss of heat, and the consequent crystal size of the minerals within this part of the unit is coarser.

The Nunobiki Granodiorite is high in $\mathrm{Sr}$ content and low in the $\mathrm{A} /(\mathrm{CNK})$ ratio, $\mathrm{Rb}, \mathrm{Y}, \mathrm{Ba}$, and $\mathrm{Nb}$. The two facies of the Nunobiki Granodiorite have similar geochemical features, lacking a negative Eu anomaly. This shows that plagioclase crystallization of the Rokko Granite and the Nunobiki Granodiorite was different. The REE patterns for both the equigranular and porphyritic facies of the Nunobiki Granodiorite, seen in Figure 7, show less negative anomalies, suggesting that these plagioclase crystals were not fractionated during crystallization of the granodioritic magma.

The Yahatadani Granite has high $\mathrm{A} /(\mathrm{CNK})$ ratios, and high $\mathrm{Sr}, \mathrm{Zr}$, and $\mathrm{Y}$, and low $\mathrm{Rb}$ and $\mathrm{Nb}$. The Nunobiki Granodiorite and the Yahatadani Granite belong to the Younger Ryoke granitic rocks (Nakaie and Nakajima, 1989; Arai and Tainosho, 2004); however, these rocks have a different geochemical and mineral composition such that the biotite of the two rocks differs. Yahatadani Granite biotite is depleted in $\mathrm{Mg} /(\mathrm{Mg}+\mathrm{Fe}+\mathrm{Mn})$ when compared with that of the Nunobiki Granodiorite. The AFM diagram suggests that the Yahatadani Granite underwent a different evolutionary process from that of the Nunobiki Granodiorite. The Nunobiki Granodiorite and the Yahatadani Granite are formed by different magmatic process. The Rokko Granite and the Yahatadani Granite are formed from magmas of similar compositions. However, the Nunobiki Granodiorite evolved from a distinct 
intrusive source.

\section{ACKNOWLEDGMENTS}

I would like to express my gratitude to Prof. Y. Tainosho of Kobe University for his support and valuable advice on my research. Prof. H. Sato gave invaluable guidance in electron probe (EPMA) microanalysis at the Kobe University Venture Business Laboratory. I also thank Prof. M. Yamamoto and an anonymous reviewer for their constructive reviews, and Prof. T. Nishiyama for editorial assistance.

\section{REFERENCES}

Arai, T. and Tainosho, Y. (2004) Lithologic variation and plutonic history of the Late Cretaceous granitoids in the Rokko Mountains, Southwest Japan. Journal of Geological Society of Japan, 110, 452-462.

Huzita, K. and Kasama, T. (1982) Geology of the Kobe District. Quadrangle Series, scale 1:50,000. Geological Survey of Japan, 1-115.

Huzita, K. and Kasama, T. (1983) Geology of the Osaka-Seihokubu District. Quadrangle Series, scale 1:50,000. Geological Survey of Japan, 1-112.

Kasama, T. (1968) Granitic Rocks of the Rokko Mountains, Kinki District, Japan. Journal of Geological Society of Japan, 74, 147-158.

Kawano, Y. and Ueda, Y. (1966) K-Ar dating on the igneous rocks in Japan(V)-Granitic rocks in southwestern Japan-. The Journal of the Japanese Association of Mineralogists, Petrologists and Economic Geologists, 56, 191-211(Japanese with English abstract).

Leake, B.E. (1978) Nomenclature of amphiboles. Canadian Mineralogists 16, 501-520.

LeMaitre R.W. (1981) GEMIX -A Generalized petrological mixing model program. Computer and Geosciences, 7, 229-247.

Matsuura, H., Kurimoto, C., Sangawa, A. and Bunnno, M. (1995) Geology of the Hirone District. Quadrang Series, scale 1:50,000. Geological Survey of Japan, 1-110.

Miyake, Y., Tsugane, T., Kanai, T. and Ikemoto, M. (1996) X-ray fluorescence analysis of glass bead pellets of a high ratio of sample to flux and accuracy of the rapid analysis. Journal of Faculty of Science, Shinshu University, 31, 105-117.

Miyashiro, A. and Kushiro, I. (1975) Petrology II, pp. 171, Kyoritsu. Tokyo.

Murata, M. and Yoshida, T. (1985) Trace elements behavior in Miocene I-type and S-type granitic rocks in the Ohmine district, central Kii peninsula. The Journal of the Japanese Association of Mineralogists, Petrologists and Economic Geologists, 80, 227-245 (Japanese with English abstract).

Nakaie, T. and Nakajima, W. (1989) Older Granites in the Southeastern Part of the Rokko Mountains. Bulletin of Faculty of Education, Kobe University, 83, 27-46.

Nakano, S., Kawab, T., Harayama, S., Mizuno, K., Takagi, T., Komura, R. and Kimura, K. (2003) Geology of the Minahuchi District. Quadrang Series, scale 1:50,000. Geological Survey of Japan, 1-121.

Nash, W.P. and Crecraft, H.R. (1985) Partition coefficients for trace elements in silicic magmas. Geochimica et Cosmochimica Acta, 49, 2309-2322.

Pearce, J.A., Harris, N.B.W. and Tindle, A.G. (1984) Trace element discrimination diagram for the tectonic interpretation of granitic rocks. Journal of Petrology, 25, 956-983.

Shand, S.J. (1947) Eruptive Rocks; Their Genesis, Composition, Classification, and their Relation to Ore-Deposits, 3rd Ed. Journal of Wiley, pp. 488, New York.

Talor, S.R. and McLennnan, S.M. (1985) The Continental Crust: Its Composition and Evolution. pp. 312 Oxford, Blackwell, England.

Terakado, Y. and Nohda, S. (1993) Rb-Sr dating of acidic rocks from the middle part of the Inner Zone of southwest Japan: tectonic implications for the migration of the Cretaceous to Paleogene igneous activity. Chemical Geology, 109, 69-87.

Uechi, T. (1937) Geology and structure of the Rokko Mountains. Journal of Geography, 49, 481-497.

Yamamoto, K. and Morishita, T. (1997) Preparation of standard composites for the trace element analysis by $\mathrm{X}$-ray fluorescence. Journal of the Geological Society of Japan, 103, 1037-1045.

Manuscript received November 202004

Manuscript accepted July 12, 2006

Published online November 24, 2006

Manuscript handled by Tadao Nishiyama 